\title{
Paradoxes of Strategic Labour Rights Litigation: Insights from the Baldia Factory Fire Litigation
}

\author{
Faisal Siddiqi
}

\begin{abstract}
This chapter focuses on the legal activism that followed the Ali Enterprises factory fire and its aftermath in Pakistan. This chapter has two purposes: firstly, it documents the legal proceedings that were initiated and pursued in the courts of Pakistan as well as its interconnected developments. Secondly, I aim to use this engagement with the legal proceedings of the Baldia factory fire aftermath as an opportunity for an in-depth reflection on the capacity and, finally, suitability of the judicial process to bring about justice in struggles over human and labour rights. Providing a rare and insider account of the legal proceedings in the Pakistani courts and its interconnected developments, I hope to lay the empirical foundation for the theoretical and strategic claims of this study. It is against the background and based on the experience with the litigation and legal advocacy following the Baldia fire that I examine the two what I perceive as "paradoxes" at the heart of the litigation. The first is the inseparability of the "limited justice" that may result from such litigation on one hand, and the "structural injustice" that informs and determines the conditions the litigation seeks to address - and transform —on the other hand. The second paradox concerns the inseparability of both law and lawlessness as regards the legal context of the litigation, advocacy and policy proposal elements that are here in play.

My argument is that these apparently contradictory phenomena not only coexist alongside one another but that they guarantee each other's existence. This analysis leads me to the conclusion that in order to understand and improve such forms of strategic litigation, it is necessary to measure its success and failure in terms of three distinct but interconnected criteria. These are the tactical, strategic and structural impacts of the litigation. Ultimately, I will argue for rejecting what is often perceived by involved stakeholders to be an unavoidable choice between nihilism, euphoria or incremental reform in this context. But, to the contrary, I will argue for a conception of legal struggles as a means of building sustainable and fruitful forms of resistance and of change based on the recognition and exploitation of these irreconcilable
\end{abstract}

F. Siddiqi $(\bowtie)$

Siddiqi, Vawda, Usman and Memon Law Associates, Advocates and Legal Consultants, Karachi, Pakistan 
paradoxes rather than fruitless attempts to ignore or transcend these irreconcilable contradictions.

For 'the law', as a logic of equity, must always seek to transcend the inequalities of class power which, instrumentally, it is harnessed to serve.-EP Thompson ${ }^{1}$

Law and lawlessness, we repeat, are conditions of each other's possibility.—Jean and John Comaroff $^{2}$

Out of the crooked timber of humanity no straight thing was ever made.-Immanuel Kant ${ }^{3}$

\section{Introduction}

The impact of labour struggles in Pakistan, crystalising, inter alia, in the evolution of the trade union movement, well intended labour legislation or pro-labour judicial decisions, has not been historically significant. But on 11 September 2012, Pakistan did make labour history, when at least 255 workers died and 55 were injured in a factory fire at the Ali Enterprises textile factory in the Baldia area of Karachi, Pakistan (Baldia factory fire). ${ }^{4}$ It was a historic tragedy because it was the highest number of deaths ever recorded as a result of a factory fire in Pakistan or elsewhere. ${ }^{5}$ Interestingly, this bloody tragedy has had the unintended consequence of revealing the paradoxical realities of the nature of law and the state, power imbalances of capital and labour, and the extraordinary exercise of judicial power in Pakistan. ${ }^{6}$

\footnotetext{
${ }^{1}$ Thompson (1990), p. 268.

${ }^{2}$ Comraroff and Comraroff (2006), p. 21.

${ }^{3}$ Quoted in Berlin (1998), p.16.

${ }^{4}$ These figures are from the Final Report of the Commission, Baldia Factory Fire Incident, Karachi, dated 28 June 2013, submitted before the High Court of Sindh in Constitution Petition No. 3318 of 2012. Although the controversy surrounding the correct number of dead and injured workers or persons in this tragedy has recently been revived because an Anti-Terrorism Court No. VII at Karachi, in Special Case No. 11(vii)/2017, through judgment dated 22 September, 2020, has given judicial findings that there were 264 deaths and 60 injured in the Baldia factory fire. As discussed below in this chapter, this Anti-Terrorism Court conducted the criminal proceedings arising out of this Baldia factory fire incident.

${ }^{5}$ This specifically refers to deaths in factory fires and not deaths in other kinds of factory incidents. Before the Baldia factory fire, the highest number of deaths was around 213 in 1993, in a doll factory fire, Thailand. See, Thai Factory Fire's 200 Victims Were Locked Inside, Guards Say. New York Times, 12 May 1993, www.nytimes.com/1993/05/12/world/thai-factory-fire-s-200victims-were-locked-inside-guards-say.html (last accessed 13 August 2020).

${ }^{6}$ I use the term "capital," "capitalist class" and "capitalist elites" at various places in this chapter as an alternative to the terms "business community" or "textile industry" in order to emphasise that these labour legal struggles are actually struggles against the neo-liberal capitalist system existing in countries like Pakistan.
} 
This chapter analyses the legal struggles arising from the Baldia factory fire, concentrating on the litigation initiated and pursued in the Pakistani courts, as well as its interconnected developments. The chapter's purpose is to answer three basic questions: firstly, what happened in these legal struggles and why? Secondly, what do these legal struggles tell us about the role of the law, judiciary and power structures in relation to labour legal struggles in countries like Pakistan? Thirdly, what can we learn from these legal struggles about the nature, the potential but also the limitations of strategic labour rights litigation as a litigation tool in countries like Pakistan? In order to answer these questions, I have divided this chapter into three parts, each dealing with one question. The first part (Story of the legal proceedings: Hope, victories and disenchantments) deals with the question as to the what and why questions of the legal proceedings in Pakistan. The second part (Strange bedfellows: Law, disorder, power relations and anarchic law) deals with the second question about the implications of these labour legal struggles on our understanding of law, judiciary and power relations. And the third part (Strategic labour rights litigation: Tactical victories, strategic possibilities, structural improbabilities) deals with the utility of strategic labour rights litigation.

Before proceeding further, it is important to clarify the following: as the litigation in Pakistan arising from the Baldia factory fire was primarily conducted by the author and his team of lawyers, ${ }^{7}$ the discussion and analysis also makes reference to, and relies on, the author's own experience of conducting this litigation. Therefore, this chapter is more than an intellectual exercise. It is also a remembrance, a celebration of sorts and a recording of the horrors of legal injustice. But most importantly, it is an attempt to arrive at a deeper understanding of these issues, through a rigorous self-critique of legal interventions in labour struggles.

\section{Story of the Legal Proceedings: Hope, Victories and Disenchantments}

Before analysing the jurisprudential and strategic legal implications of the litigation regarding the Baldia factory fire, it is critically important to describe and to understand the litigation and its interconnected developments. Mere abstract conceptualisations or empirical generalisations on the basis of selective victories or defeats will deprive us both of an understanding of the complexities of these struggles and complex implications for future strategic labour rights litigations. In short, we must confront the positive as well as the uncomfortable truths of these complex legal battles regardless of whether they dampen the celebratory narrative of this struggle or whether they question the a priori ideological and theoretical presumptions of a legal nihilism which seems to be constantly suspicious of judicial remedies. Therefore, this section describes and analyses the Baldia factory litigation

\footnotetext{
${ }^{7}$ I would like to thank my colleague, Muhammad Vawda, for his contribution in this litigation.
} 
and its interconnected developments in three parts: First, the two public interest constitutional petitions ("petition") initiated and pursued at the High Court of Sindh at Karachi, Pakistan ("Sindh High Court"). ${ }^{8}$ Second, the criminal case initiated by the Sindh government at the criminal courts at Karachi against the owners and management of the Ali Enterprises factory and various government officials. Third, the passage of a new workplace safety law and the settlement agreement regarding long-term compensation for the victims of the Baldia factory fire under the mediation of the International Labour Organization.

\subsection{Public Interest Constitutional Litigations}

The litigation strategy adopted was both unusual and eccentric. Instead of pursuing the remedy of tort claims on behalf of the victims ${ }^{10}$ under the Fatal Accidents Act (1855), or pursuing the remedy under the Pakistani labour laws, two constitution petitions were filed before the Sindh High Court, seeking multiple reliefs on behalf of the victims of the factory fire. These two constitution petitions were filed under Article 199 of the Pakistani Constitution of 1973, which allows public-spirited persons and organisations to seek the enforcement of fundamental constitutional rights, ${ }^{11}$ such as the right to life and the right to justice, ${ }^{12}$ on behalf of a group of aggrieved persons, such as the victims of the Baldia factory fire. ${ }^{13}$

\subsubsection{Constitution Petition No. 3318 of $2012^{14}$}

This was the primary case of this Baldia factory litigation but it was an unusual petition in two respects. First, the petitioners in this case were labour union organisations, NGOs and publicly-spirited individuals but none of the petitioners were either victims of the Baldia fire or any organisation or union ${ }^{15}$ of workers of the Ali Enterprises factory. In other words, it was a petition for the victims but without the

\footnotetext{
${ }^{8}$ One of the Provincial High Courts in Pakistan.

${ }^{9}$ Provincial government of the province of Sindh, Pakistan.

${ }^{10}$ The use of the word "victims" in this article includes both the legal heirs of the deceased workers and the injured persons.

${ }^{11}$ For an overview of public interest litigation and the expansion of judicial review in Pakistan, see Khan (2014), p. 284; Siddiqi (2015), p. 77.

${ }^{12}$ Articles 4 and 9 of the Constitution of Pakistan, 1973.

${ }^{13}$ Article 199 of the Pakistani Constitution,1973, is a constitutional remedy under which public interest litigations can be initiated for the enforcement of fundamental rights. Fundamental rights are contained in Chapter 1, Part II, of the Constitution, 1973.

${ }^{14}$ The information and documents relied upon in these sections are based on the actual court record of this case.

${ }^{15}$ The Ali Enterprises factory was an unregistered factory with no trade union.
} 
victims. Second, the reliefs sought in this case were multifold and numerous, ranging from seeking a proper investigation into and the assigning of liability for this incident to labour institutional reforms and compensation for the victims. In other words, this petition had a highly ambitious litigation agenda. Why was such a strategy adopted? Three main reasons can be identified. First, in view of the grand scale of this tragedy and urgent needs of the victims, this petition was filed within a week of the factory fire. ${ }^{16}$ As a result, only a few organisations and persons were interested in instituting this case in such emergency circumstances. Secondly, although the Pakistan Institute of Labour Education and Research (PILER) and the National Trade Union Federation (NTUF) (both of which were petitioners) were in contact with the victims but no victim family or injured person in those early days could be convinced to become a petitioner in this case. As it became evident later, this lack of interest by the victims was a result of their scepticism about the law and courts and more importantly, the result of fear due to threats as well as incentives received from the Ali Enterprises factory owners. Third, a constitution petition seemed the only effective litigation option available because it was practically and financially impossible to file 310 tort claims on behalf of the families of the deceased and injured in the civil courts. ${ }^{17}$ In order to institute such tort claims, the basic task of locating all the legal heirs of the victims and injured was a longer-term undertaking with insurmountable difficulties and also without the prospect of any immediate financial relief being provided to the victims because such tort litigation has a minimum litigation life of 15-20 years. Also, as there was no immediate external funding available for this litigation, the only cost-effective remedy was a constitution petition on behalf of all of the victims. ${ }^{18}$ Furthermore, as explained below, the other possible remedies, including remedies under existing labour laws, were either toothless or absent.

\subsubsection{Relief}

The reliefs that were sought through this petition can be divided into four parts. First, it sought the constitution of a judicial commission to investigate this tragedy, to assign liability, to determine compensation and make recommendations for future prevention of such tragedies, including labour reforms. Second, it sought a declaration that the victims were entitled to compensation from both the owners of the factory and the government. Third, it sought effective prosecution of the criminal

\footnotetext{
${ }^{16}$ The first hearing of Constitution Petition No. 3318 of 2012 was held in the Sindh High Court on 18 September 2012, that is, within a week of this tragedy.

${ }^{17} 255$ persons dead and 55 injured.

${ }^{18}$ The court fee for instituting such a petition was less than 10 euros but this does not include either the professional fee of lawyers and other miscellaneous expenses of such litigation. Court fee for instituting each tort claim is 15,000 Pakistani rupees (80 euros), a substantial amount in Pakistan especially when multiplied by 310 claims. As Pakistan has no civil legal aid system, the entire cost of the Baldia factory fire litigation was financed by the author himself, through his legal practice.
} 
case against the owners and management of the Ali Enterprises factory and various government officials. ${ }^{19}$ Fourth, it sought the inspection and survey of all factories and establishments in the province of Sindh. ${ }^{20}$

\subsubsection{Identification of Unclaimed Bodies}

As noted above, the scope of this constitution petition was manifold, but the court proceedings came to be dominated by two issues: compensation and the identification of unclaimed bodies, which had paradoxical implications for the wider objectives of this litigation. The Sindh High Court in this case passed various orders to identify over 70 unclaimed victims but in the end, around 16 victims could still not be identified. These unidentified victims were finally buried on the orders of the Sindh High Court. ${ }^{21}$ The issue of unclaimed victims became dominant for two main reasons. Firstly, the emotional nature of this issue led the Sindh High Court to give it priority. Secondly, the complete failure of the government to prioritise this sensitive issue was aggravated by the logistical fact that at that relevant time the entire Sindh province did not have a single DNA lab for testing and the samples of these unclaimed victims had to be sent to the capital city, Islamabad. Thirdly, the issue of compensation for the legal heirs of the deceased workers was linked with the identification of their deceased loved ones which meant that where no identification was made possible, no compensation could be claimed. Paradoxically, this issue was not anticipated at the time of the petition's filing nor was there a specific relief or prayer sought regarding this issue in the petition. Nevertheless, this issue came to dominate the court proceedings in comparison to other equally important issues.

\subsubsection{Judicial Commission and Compensations}

As noted above, the constitution of the judicial commission that was sought through this petition had a broader mandate, namely to investigate this tragedy, to assign liability, to determine compensation and also to make recommendations for labour reforms in order to prevent such tragedies in the future. But the judicial commission constituted by the Sindh High Court, within five months after the filing of this

\footnotetext{
${ }^{19}$ I do not discuss the various court orders passed regarding the criminal case in this section because they are discussed below in Sect. 2.3 which deals with such criminal proceedings.

${ }^{20} \mathrm{Sindh}$ is the second biggest province of Pakistan with a population of over 45 million people. The petitioners prayers for effective criminal prosecution and the inspection and surveying of all factories and establishments was simply about seeking the enforcement of the existing statutory obligations of the state under the Criminal Procedure Code, 1898, and the Factories Act, 1934.

${ }^{21}$ Orders passed in Constitution Petition No. 3318 of 2012 between October 2012 and December 2014.
} 
petition, ${ }^{22}$ was limited in its scope to the identification of the victims, their legal heirs and the determination and payment of the compensation to them.

Why were these strategic goals with respect to the broader mandate of the judicial commission abandoned for the tactical goal of expeditious immediate compensation $?^{23}$ The following reasons can be identified: firstly, there was an accepted underlying presumption among the parties involved as well as a public perception that limited justice in the form of immediate compensation had priority over the strategic goals of substantive justice and labour reforms. Secondly, as an unintended consequence of PILER spearheading this petition, PILER was able to get KiK Textilien und Non-Food $\mathrm{GmbH}(\mathrm{KiK})$ on the negotiating table despite the fact that $\mathrm{KiK}$, which was the main buyer of textile goods from the Ali Enterprises factory, accepted no role and no liability with respect to the fire. Consequently, on behalf of the victims of the factory fire, PILER entered into an agreement with $\mathrm{KiK}$ on 21 December 2012, in which KiK, among other things, agreed to provide immediate relief of one million US dollars for the victims. One of the main clauses of this agreement also mandated that the disbursement of this compensation be done through a judicial commission constituted by the Sindh High Court. Furthermore, negotiations regarding the long-term compensation with KiK were also dependent on the successful completion of the disbursement of this initial immediate compensation through the judicial commission. Thirdly, the main reason why all parties to the proceedings (petitioners, factory owners and the government), consented to the constitution of the judicial commission was because of its limited focus on immediate compensation, otherwise any insistence on a judicial commission with a broader mandate might have delayed the expeditious determination and disbursement of this immediate compensation. In other words, in order to expedite the compensation to the victims, a consensual process was adopted and as a result, limited justice in the form of immediate compensation trumped the broader goals of substantive justice and labour reforms. Fourthly, the main reason why the Ali Enterprises factory owners agreed to contributing towards the amount of compensation was because they were confined to jail as a consequence of the criminal case against them. It was a strategic decision by the petitioners to expedite the compensation issue before the owners got out of jail on bail because it was more likely that they may not consent to such a judicial commission if the pressure of the criminal case was lifted on them by the grant of bail. ${ }^{24}$ Fifthly, there had already been three investigation and inquiry reports into the Baldia factory fire, namely initial reports by the investigation committee of the police, an investigation report by the Federal

\footnotetext{
${ }^{22}$ Order dated: 1 January 2013, passed in Constitutional Petition No. 3318 of 2012 by the High Court of Sindh, Pakistan.

${ }^{23}$ I discuss the issue of strategic and tactical goals and limited and substantive justice in Sects. 3 and 4 of this chapter.

${ }^{24}$ Based on the author's personal assessment following conversations with the lawyers representing the factory owners, it seems that the owner's thought that giving compensation would increase their chances of getting bail, as this act of "generosity" might create a favourable impression in the perception of the public and the judiciary for the purposes of the grant of bail to them.
} 
Investigation Agency, and a Judicial Tribunal's Report, ${ }^{25}$ all of which broadly established the owner's liability and the gross negligence of government officials. In the presence of these reports, it became difficult to convince the Sindh High Court to constitute another inquiry commission. But as the criminal case proceeded, it became obvious that it was a strategic mistake not to insist on another judicial commission of inquiry because a report by such a judicially constituted independent commission might have prevented the eventual subversion of the criminal case, which is analysed below.

The judicial commission constituted by the Sindh High Court was headed by a retired judge of the Supreme Court of Pakistan. ${ }^{26}$ The commission submitted its final report on 28 August 2013, i.e. within six months of its constitution. The commission's proceedings and report became the foundational document for all future calculations and procedures of disbursing compensation to the victims. ${ }^{27}$ It is important to note three aspects of the commission's proceedings and the report. Firstly, for the first time, it was determined on the basis of concrete evidence that there were 255 deceased persons and 55 injured persons in the fire. Secondly, legal heirs of each deceased person were paid 610,000 Pakistani rupees (3216 euros) in total, each permanently disabled person was also paid 610,000 Pakistani rupees, persons with grievous injury were paid 250,000 Pakistani rupees (1318 euros) and persons with simple injury were paid 125,000 Pakistani rupees (659 euros). Thirdly, a procedure was laid down for the separate disbursement of compensation to each legal heir directly, which was especially important for the women heirs, and the share of the minor legal heirs was deposited with the Sindh High Court until they reach the age of majority. This procedure was adopted in light of the persistent complaints regarding the earlier disbursement of compensation by the government as

\footnotetext{
${ }^{25}$ This tribunal was constituted by the Sindh government and operated under the chairmanship of a retired judge of the Sindh High Court.

${ }^{26}$ The Supreme Court of Pakistan is the apex court in Pakistan.

${ }^{27}$ The amounts of disbursement by the judicial commission came from two sources, namely, as noted above, 1 million US dollars immediate compensation given by KiK under the Agreement dated 21 December 2012, with PILER and 51,800,000 Pakistani rupees (237,086 euros), along with an additional amount of 10 million Pakistani rupees (52,719 euros), was deposited by the owners of the Ali Enterprise factory. It may be noted here that the principal amount of 51,800,000 Pakistani rupees (237,086 euros) deposited by the owners was not a voluntary contribution but was a liability imposed against the owners through order dated 26 December 2012 by the Commissioner for Workmen Compensation for the 259 deceased workers under the Workmen Compensation Act, 1923, and although the owners contested this adjudicated award of the Commissioner for Workmen Compensation but due to the proceedings in this petition and the criminal case, they strategically decided to consent to deposit this amount with the judicial commission. Therefore, the total amount for disbursement as compensation with the judicial commission was PKR 165,495,000 Pakistani rupees (872,403 euros). Two further points of clarification may be noted. Firstly, it was wrongly assumed at that time that there were 259 deceased and not 255 deceased. The authenticated figures are given in the final report dated 28 August 2013 of the Commission, Baldia Factory Fire incident, Karachi. Secondly, all rupee to euro conversions in this text are according to the exchange rates on 10 July 2020.
} 
having been monopolised by a single male or elderly member of the deceased family, which led to the frequent denial of shares due to the rest of the legal heirs.

Once a firm foundation was laid by the judicial commission, the path was established for further and easier disbursement of compensations to the victims. However, the issue which arose was that there were apparently no additional funds available for further disbursement. But on an examination of the various replies submitted by the government in these court proceedings, we found an ambiguous announcement by the then Prime Minister Yousuf Raza Gilani in the year 2012 about the death grant for each deceased worker from the Workers Welfare Fund. ${ }^{28}$ Although a serious legal challenge could have been raised as to the validity of such payments to the victims from the Workers Welfare Fund, the government failed to raise such legal objections and agreed to deposit these death grants. ${ }^{29}$ Therefore, the Sindh High Court directed the government to deposit an amount of 129,500,000 Pakistani rupees (682,734 euros) with the office of the Sindh High Court, which was to be disbursed by an officer of the Sindh High Court to the legal heirs of the deceased workers. ${ }^{30}$ As a result, 500,000 Pakistani rupees (2636 euros) were disbursed to the legal heirs of each deceased worker following the same procedure as had been laid down by the judicial commission. As compared to the initial disbursement of compensation by the government, the disbursement of the compensation by the Sindh High Court (earlier through the judicial commission and later through an officer of the high court) was based on an objective criterion of entitlement and was also administered through a transparent and verifiable process.

Moreover, regarding the initial disbursement of compensation by the provincial and federal governments, there had been persistent complaints about the actual disbursement of this compensation to the victims. ${ }^{31}$ The Sindh High Court directed the government officials to submit a report to verify the disbursement of direct payments by the governments of 700,000 Pakistani rupees (3738 euros) per deceased worker and other amounts disbursed to the injured. ${ }^{32}$ Resultantly, the entire record of such payments was filed and the following aspects of this record may be noted. Firstly, payments were made to 252 out of the 255 families of the deceased workers and smaller amounts were disbursed to only nine injured persons. Secondly, the disbursement of the compensation was made to one of the male or to an elderly member of the family, leading to this disbursement being monopolised or misused by the receiving legal heir, which resulted in the frequent denial of shares due to the rest of the legal heirs.

\footnotetext{
${ }^{28}$ This was established under the Workers Welfare Fund Ordinance, 1971.

${ }^{29}$ An example of the anarchy of the law, which I will discuss in Sects. 3 and 4 of this chapter.

${ }^{30}$ Court orders dated 29 April 2014, and dated 19 November 2014. As these were limited to death grants, the injured persons were not disbursed any compensation from this amount.

${ }^{31}$ This was disbursed by the government in the first few months after the Baldia factory fire.

${ }^{32}$ Order dated: 4 April 2014, passed in Constitution Petition No. 3318 of 2012, by the High Court of Sindh, Pakistan.
} 
Furthermore, there were also persistent complaints about the lack of payments by the social security institutions, namely, the Employees' Old-Age Benefits Institution (EOBI) and the Sindh Employees' Social Securities Institution (SESSI), who were not making due payments to the heirs of all the deceased workers. ${ }^{33}$ Therefore, in view of the reports sort by the Sindh High Court from EOBI and SESSI regarding these disbursement, there was a manifold increase in the number of pensions granted for the deceased workers. For example, EOBI increased the number of pensioners from 177 to 245 . But it is important to note several aspects of these social security payments: firstly, most of the amounts were pathetically low, for example the death grant from SESSI was 5000 Pakistani rupees (43 euros) per a deceased's family. Secondly, the pensions given by the EOBI were time-bound for only five years. Thirdly, although there was improvement in the numbers of the legal heirs getting the social security payments, some claims were still pending in 2016 because of bureaucratic hurdles. Fourthly, even though neither the EOBI or SESSI were parties to this petition nor was any specific relief sought against them in this petition, the Sindh High Court issued directions against them, which these social security institutions complied with without any legal objections. Usually, directions are issued only to parties to the petition. ${ }^{34}$

\subsubsection{Inspection and Surveys of Factories and Establishments}

At the heart of the Baldia factory fire tragedy was the fact that the Ali Enterprises factory was neither registered with the Labour Department nor had any occupational safety inspection ever been conducted in this factory by the department. One of the petition's strategic labour reform objectives was the large-scale registration and inspection of factories and establishments in the Sindh province. The Sindh High Court directed the registration and inspection of all the factories and establishments in the Sindh province and it ordered the submission of a compliance report to the court regarding this issue. ${ }^{35}$ In compliance with the aforementioned court orders, the Labour Department submitted a report in 2012 stating that 813 new factories and establishments had been registered, 180 new inspections had been carried out and the authorities had initiated action against 75 factories. It is important to note that the Labour Department in their comments before the court accepted their inability to enforce the law in registering and inspecting these workplaces. This institutional inability can mainly be explained as a result of the ban on surprise inspections, widespread non-implementation of the building codes, the lack of a specific

\footnotetext{
${ }^{33}$ EOBI is established under the Employee's Old-Age Benefits Act, 1976, and SESSI was established under the Provincial Employees Social Security Ordinance, 1965 (now repealed and replaced by a new law, the Sindh Employees' Social Security Act, 2016).

${ }^{34}$ Another example of the anarchy of the law, which I will discuss in Sects. 3 and 4 of this chapter.

${ }^{35}$ Orders dated: 5 November 2012 and 13 November 2012, passed in Constitution Petition No. 3318 of 2012, by the High Court of Sindh, Pakistan.
} 
occupational safety law, as well as the insignificant penal consequences for labour law violations, and so forth. In short, the enforcers themselves testified to the legal and institutional breakdown of the framework of labour law. This was indeed a promising start and could have led to a strategic breakthrough in this petition. In the end, however, nothing happened beyond that because of the overwhelming focus in the proceedings on issues of compensation and identification of unclaimed bodies. In short, there was a lack of interest and support among the various stakeholders (i.e. victims, NGOs, judges) in their failure to prioritise labour reform through the registration and inspection of factories and establishment.

At this stage, a few general observations regarding these constitutional petition proceedings are necessary. Firstly, the limited success (reasonable compensation etc.) in this petition cannot be understood without the role played by two individuals, namely Justice Maqbool Baqar, the judge of the Sindh High Court (now serving at Pakistan's Supreme Court) who passed most of the important orders in this petition, and Retired Justice Rahmat Hussein Jafferi, who presided over the judicial commission. Without the contribution of these two judges, the limited success achieved in this petition would not have been possible. Secondly, at least at the initial stage and at various other times, the facilitating role played by the provincial and federal governments in these proceedings proved important. ${ }^{36}$ Thirdly, the proceedings' limited success also depended on the disclosure of various information and documents made available to the petitioners through the orders of the Sindh High Court. Therefore, these proceedings became a vehicle for the discovery of the unknown and hidden facts regarding this tragedy and also these key pieces of information contributed to the success of this petition. Fourthly, serious questions regarding the legal maintainability of such a petition were surprisingly never seriously raised by the opponents nor adjudicated upon by the Sindh High Court. As examined below, this anarchy in the law laid the foundation for the victim's substantive compensational victories.

\subsection{Constitution Petition No. 295 of $2013^{37}$}

In view of new developments and the surfacing of previously unknown facts, a second constitution petition was filed by labour rights organisations, NGOs and public-spirited individuals seeking the following reliefs: firstly, an injunction against the Prime Minister of Pakistan to restrain him from interfering in favour of the owners and management of Ali Enterprises factory in the criminal case instituted

\footnotetext{
${ }^{36}$ Due to the present constraints of space, the author is unable to discuss and explore whether the state in the postcolony and the Global South have become completely co-opted by the forces of capital or if there is still hope for a progressive state capable of checking anti-labour practices in such countries.

${ }^{37}$ The information and documents relied upon in this section is based on the actual court record of Constitution Petition No. 295 of 2013 filed before the High Court of Sindh, Pakistan.
} 
against them. ${ }^{38}$ Secondly, directions were sought against the relevant authorities to initiate proceedings regarding the building code violations in the factory. Thirdly, directions were sought against the Labour Department to initiate proceedings against the factory owners for violations of the labour law. Fourthly, directions were sought against the authorities to initiate proceedings against RINA Services SpA, Italy, and their Pakistani affiliate Regional Inspection \& Certification Agency (Pvt) Limited, for issuing the false and faulty SA8000 certification, which deliberately misrepresented and underreported the actual and largely non-existent occupational safety measures in the Ali Enterprises factory.

\subsubsection{Labour Law Violations}

The bombshell dropped in this case was the disclosure by the Labour Department that the Ali Enterprises factory, which employed more than 1500 workers and was a major exporter of textile goods, had not even been registered with the Labour Department. In short, an export-producing textile factory was operating in the industrial heart land of Karachi and employing hundreds of workers without even being registered with Labour Department. Since it was never registered, it was never subjected to any labour or safety inspection by the Labour Department and this was the legal defense taken by the Labour Department. Incongruously, a small percentage of its workers was actually registered with the social security institutions like the EOBI and SESSI but not with the Labour Department. It appeared like a fictional story, clearly betraying the collusive relationship between the capitalist class and the labour regulators. In other words, the state's defence in this tragedy can be captured by the motto "see no evil" (i.e. no registration and thus, no statutory obligation to regulate) and thus, "cannot prevent any evil" (i.e. no responsibility could be assigned for this industrial tragedy on the Labour Department).

But the tragedy did not end with this nonsensical and Machiavellian defense of the Labour Department as to why it had never inspected or regulated this factory. After the Baldia factory fire, the Labour Department did initiate a case against the Ali Enterprises factory owners under the 1934 Factories Act and the 1975 Sindh Factories Rules promulgated under the 1934 Factories Act, but they were charged for an offence under Section 64 (Penalty for failure to give notice of accidents), which imposed a penalty of 500 Pakistani rupees (2.66 euros). ${ }^{39}$ This is a minor violation with an insignificant and laughable penalty for the biggest death toll in a factory fire in human history. In fact, there were no provisions in the labour laws which contained any substantial and deterrent penalties, under which the factory owners could be charged with. In short, the Labour Department was helpless not

\footnotetext{
${ }^{38}$ In order to understand the significance of the orders passed by the Sindh High Court against the interference by the prime minister, see below Sect. 2.3.2 dealing with the criminal case of this chapter.

${ }^{39}$ Section 64, Factories Act, 1934, which lays down the penalty for failing to report any accidents.
} 
only due to its collusive behaviour but also because the labour laws under which it operated were toothless even in the face of such a grave industrial tragedy.

\subsubsection{Building Code Violations}

One of the tragic surprises of this case is that one of the main reasons for such a large death toll was caused due to the dangerous conditions created by the violations committed by the owners in the factory's building structure. As the FIA report notes:

owners of the factory committed flagrant violations of approved building plan. The illegal wooden mezzanine floor between the ground and $1^{\text {st }}$ floor was the main cause of aggravation of fire and its spread to upper floor [...] rapid burning of the illegal mezzanine floor not only blocked the staircase but also made the fire spread quickly to the $1^{\text {st }}$ and $2^{\text {nd }}$ floor through the duct available around the cargo lift. ${ }^{40}$

To confirm these buildings code violations, the Sindh High Court ordered an independent building inspection of the factory and unsurprisingly, multiple violations in the construction of the structure of the factory building were promptly discovered.

Were these violations simply due to the corruption or weakness of the building regulatory regime? This would be too easy an explanation. Rather, the cause of these building violations is much more fundamental. The Ali Enterprises factory was located in the Sindh Industrial Trading Estates (SITE), which is the biggest industrial area in Karachi. The Sindh Building Control Authority (SBCA) took the defence before the court that it had no jurisdiction to check building violations in the SITE area and that it was actually the public duty of the management of SITE to issue building plans and check building infringements. This gave rise to both a legal and an enforcement problem: under what law has the management of SITE been issuing building plans for the factories in its area as it is only a leasing authority and not a building authority; and furthermore, how could SITE enforce the rectification of these building violations as it lacked both the technical infrastructure and legal penal framework including a statutory building code? In Karachi, only the Sindh Building Control Authority had the technical expertise and legal enforcement framework, supported by a statutory building code, to enforce violations of building codes. But it should be noted here that this issue of jurisdiction of the SBCA in the SITE area is still pending before the Sindh High Court in this very petition and has yet to be resolved.

\footnotetext{
${ }^{40}$ Federal Investigation Agency, Sindh Zone, Karachi, "Enquiry Report: Fire Incident At Ali Enterprise S.I.T.E Karachi On 11th September 2012”, 3 October 2012.
} 


\subsubsection{RINA and Private Inspections}

In view of the suspension of surprise labour inspections in the Sindh province since 2001, and due to the lack of capacity and institutional corruption of the Labour Department to enforce even the minimum occupational safety standards, led to the domination of the smokescreen of voluntary social standards certificates issued by private international inspection companies.

On 3 August 2012, 39 days before the Baldia factory fire, RINA Services SpA from Italy (RINA), issued a certificate that the Ali Enterprises factory was in compliance with the standard SA8000, based on an audit and inspection conducted by its Pakistan affiliate, Regional Inspection \& Certification Agency (Pvt) Limited, which falsely certified that among other things health and safety procedures were complied with by the factory. The audit report of the factory falsely stated that fire extinguishers and fire safety buckets were available, accessible exit doors were kept unlocked and there were regular emergency drills and firefighting training conducted at the factory.

The investigation report by the Federal Investigation Agency, ${ }^{41}$ the Judicial Tribunal's Report ${ }^{42}$ and the reply submitted by the chief fire officer of the local government in this petition, all clearly point out that there was a complete absence and failure of fire safety standards at the Ali Enterprise factory. It follows that the SA8000 certification given by RINA was not simply an example of a factually incorrect report but in fact symbolises a fraudulent system of private inspections. In the replies filed by RINA and its Pakistani affiliate in these proceedings, there was a denial of any responsibility and liability, but two facts still point towards at least an implied acceptance by RINA of this fraudulent system. Firstly, these companies suspended all SA8000 certifications issued in Pakistan. Secondly, both RINA and its Pakistani affiliate were disbanded in Pakistan.

Through various orders passed by the Sindh High Court, this petition achieved two objectives in relation to these private inspections. Firstly, this fraudulent private inspection system was exposed and RINA suspended its activities in Pakistan. Secondly, the Sindh High Court directed RINA to provide a complete list of all entities or companies to which SA8000 certificates had been issued and it further directed the Labour Department to re-inspect all these entities or companies to which RINA had issued these certificates. The Labour Department re-inspected all these factories based in the Sindh province and it informed the Sindh High Court that the violations of labour laws have been communicated to these entities or companies. However, there was no independent means to assess the validity and quality of these inspections conducted by the Labour Department itself.

\footnotetext{
${ }^{41}$ Federal Investigation Agency, Sindh Zone, Karachi, "Enquiry Report: Fire Incident At Ali Enterprise S.I.T.E Karachi On 11th September 2012", 3 October 2012.

${ }^{42}$ This tribunal was constituted by the Sindh government under the chairmanship of a retired judge of the Sindh High Court.
} 
On the crucial question as to whether any action could be taken against RINA and its Pakistani affiliate, the Labour Department demonstrated its complete helplessness since there was no law which mandated or regulated private certifications like SA8000 nor were such certificates submitted to and vetted by any statutory authority. Resultantly, RINA and its Pakistani affiliate had actually violated no law by giving a false report. At best, they could be found guilty of violating their contractual obligation towards their clients, e.g. Ali Enterprises. But their clients stood to benefit from such fraudulent inspections and could hardly complain. Therefore, the absence in the law of an effective occupational safety law, the institutional weakness of the Labour Department to enforce even the weak law that existed and the complete non-regulation by the state of these private inspections led to this grave tragedy.

The above narratives of the lack of effective labour laws, ineffective building laws and lack of regulation of a private inspection system share a common theme: in order to avoid detection and rectification of illegalities, there was a deliberate invention of legal vacuums, legal confusions and a deliberate weakening of the enforcement structures. In other words, this deliberate lawlessness and anarchy of the law was not accidental but deliberate as it served the interest of capitalist class. ${ }^{43}$

\subsection{Criminal Case: A Comedy of Horrors ${ }^{44}$}

With the hope for holding accountable the owners and management of Ali Enterprises factory and their colluding and negligent government officials, under the labour or regulatory laws, dwindling and disappearing, the only legal option available for such accountability was through the criminal law, i.e. the imposition of criminal liability for gross criminal negligence under the Pakistan Penal Code, 1860, (PPC). ${ }^{45}$ But like a tragic comedy, a cruel drama of injustice was in the process of being performed through the criminal justice system, which would destroy any semblance of accountability and instead tragically further strengthen the impunity from accountability of the capitalist class by facilitating the legal, moral and social rehabilitation of the owners of Ali Enterprises factory. ${ }^{46}$

\footnotetext{
${ }^{43}$ These notions of lawlessness and anarchy are examined in Sects. 3 and 4 in this chapter.

${ }^{44}$ The information and documents relied upon in this section are based on the actual court record of this case.

${ }^{45} \mathrm{PPC}$ is the main criminal statute in Pakistan, which contains the main criminal offences.

${ }^{46}$ As explained in detail in Sect. 2.3 below, the owners emerged also as the victims of this tragedy as they were substituted in the criminal case from being accused persons to becoming victims and innocent witnesses of this tragedy by the prosecutors and as a result, this restored the owners' moral and social position in society.
} 


\subsubsection{Act 1: The Illusive Hope}

A criminal case was initiated when the first information report (FIR) No. 343 of $2012,{ }^{47}$ was registered by the Pakistani state itself against the owners and management of the Ali Enterprises factory and various government officials, including officials of the Labour Department, SITE, Social Security Department etc. The police investigation report and the Federal Investigation Agency report that were mentioned above had concentrated more on the broader question as to why there was such a large number of deaths from the fire rather than the narrow question of how the fire started. In short, the real issue became as to the cause of the mass deaths resulting from the fire within the context of unsafe working conditions, labour law and building law violations, and as to who was individually and institutionally criminally liable for these unsafe conditions and legal violations. As explained in these reports, the cause of these mass death was identified in the following major acts of commission and omissions:

(a) Safety measures and firefighting measures in the factory were highly inadequate, i.e. there were no smoke alarms due to which the workers were alerted late, hydrants were non-functional and the staff was not trained to use such hydrants. Even otherwise, no attempt was made to extinguish the fire by the factory management.

(b) Rapid burning of the illegally constructed wooden mezzanine floor accelerated the fire and blocked the staircase.

(c) Due to alleged threat of theft, two exit doors of the second floor were permanently sealed by the factory owners and management. This sealing was fatal as most of the workers were gathered on the second floor because it was pay day and once the electricity went off it was extremely difficult for the workers to find their way in the dark.

(d) Due to alleged threat of theft, the windows were permanently sealed with steel grills. Thus, the workers could not even escape through the windows, considering the exit doors had also been sealed.

(e) The factory which employed over 1500 workers and was situated in the biggest industrial area of Karachi, was neither registered nor inspected for fire safety purposes by the Labour Department. Even the Social Security Departments had registered less than 270 workers. Therefore, the collusion and the negligence of these government departments was clear.

As far as the cause of the fire is concerned, the investigations concluded that it was an accidental fire either caused by a localised short circuit or by some negligent act of a worker. The investigation further concluded that although the possibility of mischief could not be ruled out, there was no evidence at all to suggest that the fire was caused due to mischief, sabotage or terrorism. As we will examine below, it is

\footnotetext{
${ }^{47}$ The first stage of the initiation of criminal case under the Criminal Procedure Code, 1898, is the FIR. The FIR was registered on 12 September 2012 (i.e. a day after the fire).
} 
this unresolved mystery about the cause of the fire which provided the opportunity to sabotage the accountability in this case. What was quite interesting about this initial phase was that the public prosecutor and police acted swiftly and decisively in this case identifying the culprits and taking a broader institutional view of the criminal liability for the mass deaths in the fire, rather than simply focusing on the traditional narrow view of identifying the individual liability in causing the fire.

Furthermore, three important judicial developments happened. Firstly, the magistrate court rejected the bail applications of the owners and management of Ali Enterprises factory and sent the owners and management staff to jail. ${ }^{48}$ The unthinkable had happened in a country where corporate actors are hardly ever held accountable, let alone criminally liable. Secondly, the magistrate court froze $80 \%$ of the funds in the bank account of the Ali Enterprises factory owners. This provided an avenue for the availability of funds for compensation to be disbursed to the fire's victims. $^{49}$ Thirdly, the magistrate court refused the request of the investigation officer to withdraw the prosecution in this case against the negligent and colluding government officials. ${ }^{50}$ Therefore, the hope of institutional accountability was kept alive but as the events unfolded, this hope for accountability could not withstand the power of capitalist elite and its strategic partnership with the authoritarian Pakistani state.

\subsubsection{Act 2: The Comedy}

It quickly became apparent that the initial accountability-seeking actions of the Pakistani state against the owners and managements of Ali Enterprises factory and the colluding government officials turned out to be tactical victories at best. The structural and strategic alliance between the capitalist elite and the authoritarian Pakistani state were revealed in a dramatic manner in a speech delivered by no less than the Prime Minister of Pakistan, Raja Pervaz Ashraf, at a function organised by the Karachi Chamber of Commerce and Industry, in which he declared that: "It is not the incumbent government's policy to harass businessmen. Authorities should reinvestigate the case and provide justice to the employers of Ali Enterprises if a wrong case has been registered against the factory owners under Section 302." ${ }^{\prime \prime}$

\footnotetext{
${ }^{48}$ The initial stage of the criminal case is conducted by the magistrate but the bail applications are heard by the session judge and it is the session judge who rejected the bail application of the owners and management of Ali Enterprises Factory through order dated 6 October 2012.

${ }^{49}$ Order dated: 14 November 2012, in the criminal case under FIR No. 343 of 2012, passed by the magistrate court.

${ }^{50}$ Order dated 14 November 2012, in the criminal case under FIR No. 343 of 2012, passed by the magistrate court.

${ }^{51}$ This speech was delivered on 29 December 2012. Quelling concerns: PM promises on-time and transparent elections: Premier Ashraf directs authorities to reinvestigate Baldia Town factory fire case. Express Tribune, 30 December 2012, www.tribune.com.pk/story/486571/quelling-concernspm-promises-on-time-and-transparent-elections (last accessed 20 July 2020); Section 302 is a penal
} 
It is important to recollect the context of this incredible statement by the prime minister: bodies of all the victims of the Baldia factory fire had still not been identified, the victims had yet to be paid all the compensation and no one had been held accountable for this historic tragedy. But at the same time, the prime minister was attending dinners by the very group of the local capitalist elites which was responsible for such tragedies and the prime minister was "distressed" about providing "justice to the employers of Ali Enterprises." In other words, even in the midst of this historic industrial tragedy, the anguish of these so-called suffering capitalists dominated the mindset of the Islamic Republic of Pakistan instead of the trauma and problems of the families of hundreds of working class dead and injured of the factory fire tragedy.

Constitution Petition No. 295 of 2013 was filed, partly to challenge this interference in a criminal case by the prime minister, and the Sindh High Court was pleased to declare that such interference as not legally permissible. ${ }^{52}$ However, such formal orders became irrelevant as through this prime minister's speech the intended message had already been conveyed to the concerned investigation officer of the Baldia factory case: find a way to get the owners and management out on bail and to dilute the substantial criminal charge against them.

With the brotherhood between the country's capitalist elite and the Pakistani state reignited, things moved at great speed on two critical fronts, namely investigation and bail proceedings. Magically, in the supplementary investigation report, the investigation officer suddenly discovered that the owners and management were not guilty of the substantive offence under Section 300 PPC, that is, the offence of gross criminal negligence amounting to murder but were rather guilty of the lesser offence under Section 322 PPC, of accidental death. While the former carries a prison sentence, the latter carries no such sentence. ${ }^{53}$ But as the owners and the management were in pre-trial detention, the more dramatic reversal took place in the bail proceedings before the Sindh High Court.

In a highly unusual instance during these bail proceedings, the investigation officer himself requested the court to grant bail to the owners and management persons whereas the public prosecutor representing the investigation officer and the State opposed the grant of bail. In short, one arm of the state (i.e. investigation officer) was opposing another arm of the state (i.e. prosecutor) on this issue. It is precisely because of this confusion and conflict within the prosecution team regarding the offences for which the accused were proposed to be charged that led to the Sindh High Court granting bail to the owners and the management personnel.

\footnotetext{
provision providing the punishment for murder in the main criminal statute, that is, the Pakistan Penal Code, 1860.

${ }^{52}$ Order dated 15 February 2013, passed in Constitution Petition No. 295 of 2013, by the High Court of Sindh, Pakistan.

${ }^{53}$ Supplementary charge sheet or investigation report in the criminal case under FIR No. 343 of 2012 was submitted on 6 January 2013.
} 
But these bail proceedings were made more bizarre by the court atmosphere. In an interview, I had recalled this court atmosphere as follows: "On the day they were granted bail in court, the entire. .I mean, what was amazing was that. . 255 people have been burnt alive so you would imagine that the court would be full with victims and their families. But the entire court room. . There were about 50, 60 people in the court room, and they were all industrialists and supporters of these people. And they were clapping." 54

Even though the Sindh High Court had ordered in Constitution Petition No. 3818 of 2012 that the criminal case should conclude within one year the battle for accountability had already been lost because on one hand, the capitalist elite and the Pakistani state were bent upon providing relief to the factory owners and management, and on the other hand, only a very few victims family members were willing to pursue the criminal case. ${ }^{55}$ On top of this, the witnesses against the owners and management were rapidly turning hostile by retracting their earlier testimony. ${ }^{56}$ But what we did not realise at that stage was that matters were going to get bizarrely worse and this comedy of a criminal case was, by design, being converted into an irredeemable tragedy.

\subsubsection{Act 3: The Tragedy}

One of the valuable but tragic lessons learnt from this litigation was that unlike the poor who were divided, disillusioned and lacked clarity about their collective interest, the capitalist elite had remarkable clarity about their collective interest.

In the year 2013, a military intelligence-led police operation had started against the Muttahida Qaumi Movement (MQM), a party which dominated the politics in Karachi using militant means. During an interrogation of one of its activists, Muhammad Rizwan Qureshi, it was revealed that someone had told him that the fire at the Baldia factory fire was the alleged result of the extortion demand made by certain members of the MQM. ${ }^{57}$ This was clearly hearsay evidence as he neither was a witness to this so-called arson attack nor did the so-called arson attackers directly inform him about this extortion and arson plan. But soon after this interrogation report became public in 2015, both the capitalist elites and the state took the common stance that certain members of the MQM were responsible for deliberately starting the Baldia factory fire for the purposes of extortion. Therefore, in a god-sent opportunity, both the interest of the Pakistani state to diminish the power of the

\footnotetext{
${ }^{54}$ Gayer (2019), p. 309.

${ }^{55}$ Even these few families later lost interest in the criminal prosecution.

${ }^{56}$ The witnesses' turning hostile and lack of the interest of the victim families to pursue the criminal cases was clearly indicative of the fact that even the victims had come to accept the entrenched power of the capitalist elites and had understood that the directions of the winds of justice was firmly in favour of the owners and management.

${ }^{57}$ The interrogation by the police and intelligence services took place on 22 June 2013.
} 
MQM through this police operation and the rekindling of the state's strategic relationship with the capitalist elites were achieved through the oldest trick in Pakistani politics: a wild conspiracy theory thrust upon an impressionable, fearinduced and chaotic public discourse.

A new investigation team was formed in 2015, which promptly declared the owners of the Ali Enterprises factory as innocent and further declared that the Baldia fire was the result of a terrorist attack by the MQM for the purposes of extortion. An examination of the criminal charge framed by the Anti-Terrorism Court against the new accused persons reveals the farcical nature of this new case. ${ }^{58}$ According to the indictment, the fire erupted due to chemical substance thrown by the accused persons; the presence of such chemical substance was remarkably discovered by a lab test conducted on samples collected 3 years after the fire and the extortion was allegedly proven by the payments made by the factory owners to members of the MQM, not before but after the fire. Strangely, the fire tragedy now had two things in common with the attacks of 9/11 in the US: both happened on $9 / 11$ and both were terrorist attacks.

In September 2020, and after converting and transposing the initial accused persons in the criminal case, namely the owners and management of Ali Enterprises factory and the negligent government officials into victims and witnesses, the AntiTerrorism Court No. VII, at Karachi, in Special Case No. 11(vii)/2017, through judgment dated 22 September 2020, delivered a bizarre but predictably tragic judgment convicting eight persons for the murder of 264 persons and 60 injured persons for various offences including but not limited to deliberating starting the fire at the Ali Enterprise factory for the purposes of extortion and such acts were declared as an act of terrorism. As a result of these convictions, two persons were sentenced to death and the rest of the four persons were sentenced to life imprisonment. ${ }^{59}$ An examination of this judgment shows that its extremity in awarding the death sentences and life imprisonment is only matched by the absurdity of its reasoning because these sentences have been awarded on the basis of contradictory, inadmissible or no evidence at all. This is because primarily, there was no reliable forensic evidence to prove that the fire was started deliberately by the convicted persons by throwing chemicals because two of the three laboratory reports did not confirm the presence of any chemical from the crime scene whereas the third laboratory report from a government laboratory surprisingly confirms the presence of such chemicals on the basis of samples obtained three years after the factory fire. Furthermore, the sentences were based on unreliable and coerced confessions, flimsy eye witnesses and dubious circumstantial evidence. ${ }^{60}$

\footnotetext{
${ }^{58}$ Framing of Charge dated: 14 February 2018, in Special Case No. 11(vii)/2017 before the AntiTerrorism Court No. VII, at Karachi, Pakistan.

${ }^{59}$ Most of the convicted persons were workers or sympathisers of the MQM and most of them worked in the Ali Enterprises factory.

${ }^{60}$ Due to space constraints, the author is unable to conduct a detailed examination of the said judgment in Special Case No. 11(vii)/2017 before the Anti-Terrorism Court No. VII, at Karachi, Pakistan.
} 
What do these dramatic developments tell us? The above relief of bail provided to, and a diluted and lesser criminal charge imposed on, the owners and management of Ali Enterprises factory and the colluding government officials, were not enough to protect the interest of the capitalist elites. Rather, the entire process of accountability underlining this criminal case of the factory fire needed a complete reversal in order to ensure a devastating blow to any possibility of labour reform. In other words, regardless of the dilution of the criminal charge, the very existence of the criminal case against the owners and management of the Ali Enterprises factory and its colluding government officials was an existential threat to the collective interest of the capitalist elite. A case which began with questioning the unsafe labour practices of the Pakistani textile industry had ended with the textile factory owners and the negligent government officials being declared as victims and by the conversion of the very nature of the criminal case into a terrorist act had resulted in forgoing any possibility of raising uncomfortable questions about unsafe labour practices in Pakistan with reference to this tragedy. This was the ultimate insult to all the hundreds of workers who lost their lives in this tragic fire and a devastating blow to the possibility of labour reform in the textile industry. Therefore, the real existing conditions of the majesty of injustice and lawlessness of the modern legal system in countries such as Pakistan had been fully exposed with blatant shamelessness by the remanufacturing and re-imagination of the criminal liability of the capitalist elite into a fictional case of terrorism.

\subsection{Labour Law Reform, ILO Settlement and Socio-Cultural Mobilisation: The Irresistibility of Hope}

With the prospect of accountability in ruin, with little hope for labour reform and with the possibility of long-term compensation exhausted, there was little scope for optimism among the victims and their families, the lawyers and activist organisations involved in this Baldia factory fire struggles. But then the "Arrangement for the settlement of the funding gap for the compensation to be delivered to the victims of the fire at the Ali Enterprises in Baldia, Pakistan on 11 September 2012" (ILO settlement agreement), ${ }^{61}$ came through under the auspices of the International Labour Organization, which gave fresh impetus to this struggle for justice.

As discussed above, as a result of the initiation of the abovementioned Constitution Petition No. 3318 of 2012 by PILER and other organisations, PILER and the German company KiK entered into an agreement on 21 December 2012 for the "Relief for the Victims of the Ali Enterprises Fire Case." This agreement obligated KiK to provide one million US dollars as immediate relief but more importantly, obligated them to contribute towards long term compensation for the victims, quantum of which was to be determined through future negotiation. This agreement

\footnotetext{
${ }^{61}$ Signed on 9 September 2016.
} 
was legally eccentric for two basic reasons. Firstly, KiK had always denied any liability regarding this tragic fire but now had contractually obligated itself towards accepting at least implied responsibility. Secondly, this was a sketchy document comprised of only two pages and a reading of this agreement showed that no lawyer had vetted it before it was signed. The reason I point this out is because if KiK had sought legal advice on this agreement, it most probably would never have been signed it, or at least the text of the agreement would have been much more detailed and inclined in favour of $\mathrm{KiK}$ because it was $\mathrm{KiK}$ which was giving the money and so was in a position to dictate the terms of the agreement. Therefore, the absence of lawyers is, at times, quite beneficial for weaker victims like those of the Baldia factory fire and as events would prove, this agreement became KiK's Achilles heel. In other words, the absence of lawyers in drafting and vetting this foundational document directly benefited the interest of justice for the weak.

Negotiations between PILER and KiK on long term compensation became stalled for a number of years. But under the auspices of the ILO, a settlement agreement for providing long-term compensation to the victims of the Baldia factory fire in the sum of 5.1 million US dollars was finally signed between $\mathrm{KiK}$ on the one hand and Clean Clothes Campaign and IndustriALL Global Union, representing the victims, on the other hand. This agreement was novel for a number of reasons. Firstly, it based the compensation on the ILO Employment Injury Benefits Compensation, 1964 (C121) and thus provided a higher amount of pensionary benefits than under Pakistani law. Secondly, it provided for a lifelong pension scheme for the victims. Thirdly, this pension scheme was to be implemented through the government run social security institution, SESSI, and was to be monitored by an oversight committee of various stakeholders.

This ILO settlement agreement was a consequence of a number of factors. Firstly, the foundation was laid by the initial agreement between PILER and KiK, which was the consequence of the constitutional litigation initiated in Pakistan. Secondly, the socio-cultural mobilisation, both in Pakistan but especially in Europe by the Ali Enterprises Factory Fire Affectees Association, Clean Clothes Campaign, the European Center for Constitutional and Human Rights, IndustriALL, NTUF and PILER, lead to public awareness and pressure regarding supply chain responsibility of multinational corporations. Thirdly, the pressure generated as a result of the initiation of litigation in Germany, in the case of Jabir and others $v$. KiK filed through efforts of ECCHR. Lastly, the role of the ILO as a trusted mediator and also the background support from the German government.

This agreement breathed new oxygen to an irresistible desire for hope in these dark times. But was this a beginning of supply chain accountability and a resurrection of responsibility by the Pakistani government by administering this pension scheme through SESSI and an implementation of a beneficial international conventions like C-121? A closer examination of this ILO settlement agreement shows that it is simply a voluntary agreement, an ad-hoc acceptance of responsibility by the Pakistani government with no obligation towards any labour reforms regarding pensionary benefits for such tragedies and no international acceptance of any supply chain liability by international buyers. In short, this much-lauded agreement turned 
out to be both a landmark settlement for the victims of this tragedy but also mere tactical success without any future prospect of supply chain responsibility, accountability of the local textile industry and social security reform. Like the above legal proceedings in Pakistan, this ILO settlement agreement seemed more like a beneficial distraction from the long-term task of reforming the global textile industry and its supply chains.

Together, the ILO settlement agreement, socio-cultural mobilisation and Baldia factory fire cases provided the impetus and pressure which led to the passage of a new workplace safety law called The Sindh Occupational Safety and Health Act, $2017 .^{62}$ Was the passage of an exclusive new work place safety law a strategic breakthrough? Apparently it did create the strategic possibility of a more effective regulation of work places but the fact is there has been no implementation of this law (e.g. no increase in number of inspectors or inspections) despite the passage of nearly three years from its enactment. Why is this lack of implementation? Firstly, the Baldia factory fire cases failed to prioritise registration and inspections of work places as a key goal and as a consequence failed to generate any socio-political momentum in favour of effective regulation of workplaces. Secondly, these laws have become like pacifier lollypops with the strategic purpose to distract and deflect real and substantive changes on the ground. This is because a demand for reform is usually satisfied by the passage of laws with full knowledge of all stakeholders that it will take many years (if not decades) to implement these laws. Even otherwise, there always exist many legal loopholes in these laws for the capitalist elite to subvert their effective implementation. ${ }^{63}$ But regardless of these problems, the irresistible desire for hope was kept alive by this new law.

\section{Strange Bedfellows: Law, Disorder, Power Relations and Anarchic Justice}

The above legal narrative about the Baldia factory cases is a complex story of law and the judicial process as a manifestation of law and disorder, the extraordinary power imbalances between capital and labour and the limited justice achieved by the victims as a result of the anarchy of law. ${ }^{64}$ One of the central paradoxes at the heart of these legal proceedings is that on the one hand, limited justice is achieved by the

\footnotetext{
${ }^{62}$ PILER played a critical role in the drafting of this new law.

${ }^{63}$ Since the focus of this article is not this new law, these loopholes are not discussed.

${ }^{64}$ Limited justice is used here as a contrast to substantive justice. Substantive justice is achieved when the main objectives (not all) of the labour legal struggles are achieved, for example, substantive compensation as a right (not voluntary) and accountability. This contrast between limited and substantive justice will become clearer as this analysis develops.
} 
victims in the form of reasonable compensation ${ }^{65}$ but on the other hand, this limited justice is linked with the lack of substantive justice, and more so, linked with structural injustice, both manifesting itself in the lack of accountability and the lack of effective labour reform. So, how do we conceptually understand this paradox, and how do we understand and operationalise these concepts of limited and substantive justice, of structural injustice and the anarchy of the law?

Before moving onto questions about the effectiveness of legal remedies, such as strategic labour rights litigation and how to measure their effectiveness for the purposes of reform or transformation through the courts, we need to ask a much more basic question - not in generic jurisprudential terms but within the context of labour rights cases like this. Does law, with its promises of rights, especially human rights and binding legal and constitutional obligations, have the ideological and institutional potential to bring about reform or transformation, especially in the power-infused arena of in-egalitarian labour relations? If the answer to this question is neither a simple "yes" nor a "no" but rather an ambiguous and contradictory answer, then the question arises as to what do these ambiguities and contradictions tell us about the limitations and potentialities of the law for the attainment of substantive justice and for reform or transformation through the law? ${ }^{66}$

In relation to the legal cases against the Ali Enterprises factory owners and KiK, one type of response to the above questions is given by the lawyers who initiated and conducted the Jabir and others v. KiK case in Germany. This answer is what I call the "revolutionary potential" view and is expressed in the following terms:

The principle of equality before the law develops rare momentum, when marginalized workers are able to force the MNE responsible for their losses and injuries to abide by civil procedure rules and to explain its legal position is lengthy writs to the courts. In this regard, claiming rights through legal proceedings can realize the "revolutionary potential" inherent to human rights [.... Although the law has its constraints as a driver of social change, strategic interventions bear a revolutionary potential [emphasis added]. ${ }^{67}$

The above revolutionary potential view does recognise the formidable structural and societal obstacles to the implementation of human rights. Despite recognising these formidable obstacles, it still sees the revolutionary potential inherent in strategic human rights litigation.

Taking a different view from the revolutionary potential view, Laurent Gayer in his study of the Baldia factory fire litigation questions as to why "the trial of

\footnotetext{
${ }^{65}$ Compensation paid to the victims was reasonable but all the compensation or damages actually due to the victims was never adjudicated by the courts nor paid to the victims. For example, the owners of Ali Enterprises factory only paid the minimum statutory amount of death compensation and some voluntary contributions and the civil claim against KiK in Germany was dismissed on a preliminary objection based on the statute of limitation.

${ }^{66}$ It is important to note here that the theoretical assertions made in this section are in the context of countries of the Global South and new constitutional democracies like Pakistan and may have limited implications for countries of the Global North.

${ }^{67}$ Bader et al. (2019), pp. 169, 171.
} 
Karachi's industrial capitalism did not happen."68 His analysis emphasises the contradictory intertwining of justice and injustice in this litigation: ${ }^{69}$

Through a detailed study of these judicial proceedings and their successive bifurcations, this chapter aims to grasp the relations of inter-dependence between a distinctly unbridled blend of capitalism, a turbulent urban environment and a state torn between the strength of the law and the "justice" of the powerful [...] In the face of a society and economy where the display of might is generally deemed to prevail over the assertion of rights, Thompson's work is a useful reminder that the effectiveness of the law as an instrument of domination in the service of the powerful rests on its apparent universality and impartiality [....] What the Baldia factory fire case also exemplifies is that outcome of these battles can never be taken for granted. Even as they serve the strategies of domination of the powerful and generate their own forms of coercion, as well as their own illegalities, legal proceedings always retain a contingent part - the historical and individual 'circumstances' [... .] which introduces some indeterminacy in the game and, as such, contributes to its reproduction. This was exemplified in the Baldia factory fire case by a handful of lawyers and judges, who, in the name of social justice did not hesitate to bend the rules. The limited and contested successes of these jurists with a cause therefore obtained less by applying the law by the book - thus entrapping the dominants into their own rhetoric of self-preservation, as Thompson would suggestthan by twisting the law in order to deliver justice [emphasis added]. ${ }^{70}$

In trying to explain this paradox of limited justice (e.g. reasonable compensation) and structural injustice (e.g. lack of accountability, no effective labour reform), Gayer relies on EP Thompson's examination of the paradoxes of the "rule of law" in his masterly study on the origins and implementation of the Black Act in eighteenth-century England. The present section of this chapter develops Gayer's analysis but also partly disagrees with his analysis. Firstly, this section further explores the structural or systemic logic of the contradiction in this paradox of law as identified by Thompson. Secondly, it argues that Gayer is incorrect to conclude that the limited success achieved in the Baldia factory fire litigation was possible by "bend(ing) the rules" or "twisting the law in order to deliver justice," but rather, as this chapter tries to show that the limited success was achieved by exploiting this paradox of the law and the anarchy of the law as prevalent in countries like Pakistan.

In describing the paradox at the heart of the rule of law, Thompson writes:

But this is not the same thing as to say that the rulers had need of law, in order to oppress the ruled, while those who were ruled had need of none [...] For as long as it remained possible, the ruled - if they could find a purse and a lawyer - would actually fight for their rights by means of law [....] If the law is evidently partial and unjust, then it will mask nothing, legitimize nothing, contribute nothing to any class's hegemony. The essential precondition for the effectiveness of law, in its function as ideology, is that it shall display an independence from gross manipulation and shall seem to be just. It cannot seem to be so without upholding its own logic and criteria of equity; indeed, on occasion, by actually being just [emphasis added]. ${ }^{71}$

\footnotetext{
${ }^{68}$ Gayer (2019), p. 288.

${ }^{69}$ Gayer (2019), p. 288. It is important to note here that in his analysis, Gayer also relies on interviews with the present author.

${ }^{70}$ See Gayer (2019), pp. 290, 292, 316, 317.

${ }^{71}$ Thompson (1990), pp. 261, 263.
} 
Without engaging in the debate about whether the rule of law is an "unqualified human good" or in the debates between a Marxist versus liberal understanding of the rule of law, ${ }^{72}$ what needs examination is how this paradoxical notion of the rule of law helps us in our understanding of the above described proceedings in the Baldia factory fire litigation. In the context of the factory litigation, Thompson's theoretical insights lead us to the following conclusions: firstly, law in a capitalist society has two contradictory purposes, both to mask, legitimise and contribute to class hegemony of capital but also to uphold the propounded liberal legalities and its foundational principles of equity and universality. But this is not a conflict which only emerges out of the application of the law but rather a systemic contradiction inherent in the very notion of the rule of law. In other words, theses contradictory purposes of the law are a structural or systemic part in the very notion of the rule of law, and this structural contradiction is converted into a legal and social conflict through legal and social mobilisation. ${ }^{73}$ Because of this systemic contradiction, the rule of law, in its ideological and institutional manifestations, always contains the possibility of equity, universality and enforcement of rights leading to a limited notion of justice. Therefore, the limited justice achieved in the Baldia factory fire litigation was a result of a substantive rule of liberal legality existing in Pakistan, in the form of labour laws, fundamental rights guaranteed under the constitution and an expansive notion of constitutional judicial review. Law may not be a panacea for complete justice in such cases but law does make limited justice possible and achievable. Secondly, this limited justice comes at a high price and is only possible because it serves a macro purpose by systemically linking itself with, rather than undermining, structural injustice. Limited justice and structural injustice are dialectical twins. Therefore, the limited justice (e.g. reasonable compensation, new workplace safety law and judicial activism in favour of the victims) was achievable and tolerated so long as the structural injustice is guaranteed, which structural injustice meant no accountability and no substantive labour reform in the textile sector. As the narrative of the above legal proceedings has shown, the forces of capital, state and the judiciary always presented a stark choice to the helpless victims. Gayer captures this predicament when he notes that:

as the courts and industrialists colluded to promote compensation as the sole response to the tragedy, these activists came to realise that "public recognition of suffering and the rights of compensation that it entails remains a largely $a d$ hoc affair and generates a political program for compensation that keeps particular demands for structural change at bay". ${ }^{74}$

The brilliance of Thompson's analysis lies in his conceptualising of this dialectical nature of justice and injustice inherent in the rule of law in capitalist societies, where justice and injustice survive and thrive on the principle of "mutual assured

\footnotetext{
${ }^{72}$ Cole (2001), p. 177; Brown (2018), p. 1391.

${ }^{73}$ Mouzelis (1999), pp. 191-195. Here, I rely on the sociological distinction between social and system integration and conflict as developed by the sociologist David Lockwood and Nicos Mouzelis.

${ }^{74}$ Gayer (2019), p. 314.
} 
survival," displaying itself even today in the same force as it did at the time of Thompson's writing. This structural and dialectical notion of justice and injustice should not be confused with the standard radical left critique which claims that to invoke liberal legalism is to win the battle but lose the war $^{75}$ because what Thompson is trying to show is somewhat different, namely that liberal legalism in protecting class hegemony also paradoxically pays a price in having to recognise, and to provide, limited justice for the powerless. In short, this injustice works both ways of this power imbalance, both for and against the capitalist elite.

At the same time, what is missing in Thompson's analysis of the rule of law is the importance of disorder and lawlessness surrounding the rule of law in liberal legal and constitutional systems of the postcolony or new constitutional democracies. What exactly is this disorder and what are the paradoxical implications of this disorder surrounding the rule of law? Law and disorder are at the centre of Jean and John Comaroff's work, who conceptualise this paradox as follows:

Do these two putative tendencies-the excessive disorderliness of post-colonies on the one hand and their fetishism of the law on the other-describe a concrete reality? [....] It is part of a much more troubled dialectic: a dialectic of law and dis/order, framed by neoliberal mechanisms of deregulation and new modes of mediating human transaction at once politico-economic and cultural, moral, and mortal. Under such conditions-and this our key point-criminal violence does not so much repudiate the rule of law or the licit operations of the market as appropriate their forms-and recommission their substance. Its perpetrators create parallel modes of production and profiteering, sometimes even of governance and taxation, thereby establishing simulacra of social order. ${ }^{76}$

This second dialectic twin of law and lawlessness or disorder surrounding the rule of law is explored by Gayer in the following terms:

Karachi's industrial capitalism can thus be characterised as an irregular production system a type of organization of the manufacture economy resorting heavily to various illegalities without completely evading legal norms and the regulatory action of the courts. Rather than by its outwardly criminal nature, this mode of organisation of the economy is thus characterised by its uneven relationship with the law [...] the judicial proceedings considered here provide an opportunity to think through the irregular nature of this production system, and more particularly to reflect upon the force of law in a society where it is constantly undermined by the illegalities of "delinquent elites" [emphasis added]. ${ }^{77}$

As described above, the manifestations of this law and lawlessness dialectic are clearly present in the Baldia factory fire litigation. On one hand, Pakistan's legal system displayed all the manifestations of a labour market regulated by labour laws, labour inspectors, social security laws and institutions, an elaborate system of legal rights and fundamental rights including the fundamental right to trade unions and an expansive tradition of constitutional judicial review to enforce such rights. But on the other hand, equally present were the following contradictory features such as

\footnotetext{
${ }^{75}$ Albiston (2011), pp. 76-77.

${ }^{76}$ Comraroff and Comraroff (2006), pp. viii, 5 .

${ }^{77}$ Gayer (2019), p. 291.
} 
outdated labour laws without stringent penalties, ${ }^{78}$ the banning of surprise inspections and completely inadequate number of inspectors, the abysmal lack of implementation of labour and social security laws, the systemic elimination of trade unions, an authoritarian state closely working with forces of capitalism and finally a judiciary which was suspicious and cautious in the enforcement of legal and fundamental rights relating to labour. ${ }^{79}$ No wonder the Baldia factory fire of 2012 and the Triangle Shirtwaist factory fire of 1911 (in New York City, US) have so much in common even though they are over a century apart. ${ }^{80}$ For example, the Triangle Shirtwaist factory fire also manifested similar aspects when compared to the Baldia factory fire, namely: 113 persons dead, ${ }^{81}$ the permanent locking of doors and lack of fire safety provisions as the leading cause of an excessive number of deaths, lack of unionisation and the factory owners not being held accountable through the judicial process. ${ }^{82}$ How can we explain this inseparable existence of the contradictory phenomena of law and lawlessness and its manifestation in the repetition of history of factory fires in the twenty-first century? Comaroff explain this paradox in the following terms: "violence and the law, the lethal and the legal, are constitutive of one another [...] Law and lawlessness, we repeat, are conditions of each other's possibility." 83

Similar to the logic of the dialectic of justice and injustice, the dialectic of law and lawlessness also exists because it is based on a hidden structural relationship of each other's toleration leading to the continuing and perplexing reality of mutually assured existence of both law and lawlessness. In other words, law is only tolerated because it is never fully implemented and lawlessness continues to exist even if the formality of law exists, mere islands of lawful implementation are tolerated and occasional justice is allowed to flourish. It is precisely due to the inseparability of law and lawlessness that a tragedy similar to the Triangle Shirtwaist factory fire of 1911 repeated itself in the twenty-first century, with its modernised legal architecture of beneficial labour laws and universal human rights.

Can this paradox be resolved? To try to resolve this paradox and the above lack of justice with the presence of continuing lawlessness, the standard liberal solution is to emphasise the enactment of more beneficial labour laws, the strict implementation of laws, more unionisation, a welfare state and a labour-sensitive judiciary. But our analysis of the Baldia factory fire litigation has suggested different conclusions.

\footnotetext{
${ }^{78}$ After the Baldia factory fire, new labour laws have been enacted in the Sindh province, for example, Sindh Factories Act, 2015 and The Sindh Occupational Safety and Health Act, 2017, but despite numerous years, these laws have yet to be implemented on the ground.

${ }^{79}$ In relation to labour rights, this cautious and suspicious judicial attitude is examined below.

${ }^{80}$ See The Triangle Shirtwaist Factory Fire, Occupational Health and Safety Administration, United States Department of Labour, www.osha.gov/aboutosha/40-years/trianglefactoryfire (last accessed 4 August 2020).

${ }^{81}$ At that time, a historical death toll in any factory fire.

${ }^{82}$ The criminal proceedings against the owners was dismissed and they were acquitted whereas the civil proceedings did not end up in any meaningful or real compensation.

${ }^{83}$ Comraroff and Comraroff (2006), p. 21.
} 
These two dialectics of justice and injustice and law and lawlessness has given rise to a recurrent and systemic anarchy of law. This anarchy of law actually is the foundational and structural reality of the legal system and not a mere aberration or exception to it. In other words, one of the existentialist requirements for the rule of law, including its notions of justice, seems to be an inherent anarchy within the genetic makeup of the rule of law. But the question which arises from the Baldia factory fire litigation is whether this institutional and practical reality of the anarchy of law should necessarily be seen as a problem or is it also a strategic opportunity to be exploited? My analysis shows that this anarchy of the law can indeed be strategically exploited by the poor, including the working class. In an interview with Gayer, I described this anarchy of law in the following terms:

Pakistan faces a huge disjunction between "the law in books" and "the law in practice" - a disjunction which, in his view, "creates anarchy about interpretation and application of the law". In the Pakistan context, the law would not be a rational architecture of legal norms bringing about certainty in matters of government and in dispensation of justice, but a source of unpredictability benefiting the shrewd and the mighty. ${ }^{84}$

In new and transitional constitutional democracies like Pakistan, this anarchy of the law arises both from the uncertainty of evolving interpretations about the scope of various rights, duties and especially the scope of judicial remedies as well as from the lack of implementation of various laws caused by state incapacity and deliberate reluctance, which in turn paradoxically creates the legal space for the limited successes in cases like the Baldia factory fire case. For example, landmark compensation and other reliefs were granted to the victims in unusual and legally questionable constitutional jurisdiction, in which the proceedings' potential legal objections against such litigation were never adjudicated upon. ${ }^{85}$ Another example is the implementation of an ILO-negotiated pensionary scheme through SESSI, even though the Sindh Employees Social Security Act, 2016 (which created SESSI) does not envisage such a pensionary scheme. ${ }^{86}$ An examination of the jurisprudential debates and comparative judicial history ${ }^{87}$ does show that legal interpretational uncertainty is a common problem in all legal systems. However, these uncertainties have acquired another radical dimension in countries of the postcolony and the Global South because such countries have experienced constitutional overthrows, weak constitutionalism and unsettled meanings of legal and constitutional provisions due to relatively short histories of liberal legalism, as well as state incapacity and

\footnotetext{
${ }^{84}$ Gayer (2019), p. 311.

${ }^{85} \mathrm{We}$ were expecting these compensation claims to be challenged on the ground that the victims were not a party to these constitutional petitions and that their proper remedy lies in filing civil claims based on tort law.

${ }^{86} \mathrm{An}$ examination of the above narrative of the Baldia factory litigation also contains other examples of this anarchy of law.

${ }^{87}$ See Schwartz (1993). Despite the passage of 230 years since the US Supreme Court first sat in 1790 , judicial debates are still waging on the interpretation of seven articles and twenty seven amendments of the US Constitution. Compared to this short US constitution, the Pakistani Constitution of 1973 has 280 Articles plus schedules.
} 
breakdown leading to an inconsistent or non-enforcement of the law and thus, creating the space for an aggressive form of judicial activism. For example, compare the legal proceedings in Pakistan with the litigation in Germany: the key difference seems to be the relatively predictable certainty about the law as applicable in such cases under the German judicial system.

I disagree with Gayer's analysis that this limited justice achieved by the victims should simply be seen as a result of the bending or twisting of the law. Rather, these achievements are the result of something much more fundamental because this anarchy of the law is based on interpretational confusions, state breakdown and reluctance, and not merely on the subversion of the law by the victims. In other words, this anarchy of the law exists between the space between legal and illegal, justice and injustice and it is precisely for these reasons that this limited justice is achieved through the exploitation of these grey areas of the law and judicial remedies. Also, this anarchy of law works both in favour of capitalist elites and labour and the strategic question is as who can mobilise, legally strategise and exploit it for their collective interest. ${ }^{88}$

Moreover, the unpredictability and uncertainty about the law, as well as contingent circumstances, also creates space for the creativity of human agency, whether of judges, lawyers or group mobilisation, and frees such litigation from the straightjackets of legal determinism. Although, space here does not allow the exploration of this debate between structure and agency in legal struggles, ${ }^{89}$ but the role of individuals (e.g. Justice Maqbool Baqar and Retired Justice Rahmat Jafferi) as well as the favourable contingent circumstances existing at that time in Pakistan's judicial history ${ }^{90}$ needs to be further explored in order to understand the contingency of legal interpretations and judicial remedies resulting in the relatively open ended nature of the trajectory of these legal struggles.

\section{Strategic Labour Rights Litigation: Tactical Victories, Strategic Possibilities, Structural Improbabilities}

Strategic litigation has been defined as "litigation of a public interest that will have a broad impact on society beyond the specific interest of the parties involved" ${ }^{\prime 91}$ or lawyering "done in the service of a political or social cause that seeks to rearrange existing state or social power relations." ${ }^{\circ 2}$ As examined above, the strategy adopted in the Baldia factory fire cases was one of strategic litigation for labour and human

\footnotetext{
${ }^{88}$ Of course, because of the balance of power, it works more for capitalist elites than for labour.

${ }^{89}$ Mouzelis (2008), chapters 1 and 6.

${ }^{90}$ This historical period was a period of great expansion of judicial review in Pakistan. See Siddiqi (2015), p. 77.

${ }^{91}$ Roa and Klugman (2014), p. 31.

${ }^{92}$ Nejaime (2011), p. 943 , footnote 3.
} 
rights enforcement including, but not limited to, justice for the victims. In other words, it can be described as strategic labour rights litigation (SLRL). The basic limitations of such litigation-based reform strategy, including SLRL, ${ }^{93}$ should analytically follow from the above examined dialectics of justice and injustice and law and lawlessness and the limited justice achieved due to the anarchy of law. But before further examining the limitations and potentialities of such litigation based reform remedies like SLRL, the first task is to determine the measurement standards of the success and effectiveness of such litigation strategies. Underlying these measurement standards are the objectives or purposes of such litigation strategies.

The debate regarding the effectiveness and success of such litigation centered on reform has responded to the type of critique exemplified by Gerald Rosenberg's classic text The hollow hope: Can courts bring about social change? ${ }^{94}$ Rosenberg had concluded that victories in litigations centered on reform are illusionary because either these victories are never effectively and substantively enforced or these judicial wins fail to have any direct or indirect favourable impact on social change or reform. Moreover, such litigation may not merely be unproductive but counterproductive by diverting resources from social and political mobilisation, de-radicalising politics and provoking legal, political and social backlash. ${ }^{95}$

There were various responses to the above "rights myth" or "hollow hope" critique, which rebuttals partly accepted this critique but still emphasised the strategic and symbolic impact of such litigation based reform remedies. ${ }^{96}$ Some of these responses are as follows:

(a) We can have "success without victory" if we reject the sharp divide between winning and losing. If success in litigation means a commitment to resist, building movements and resistance litigation becoming part of a community of memory then even defeat in litigation is neither fatal nor the priority. ${ }^{97}$

(b) We can achieve "winning through losing" as judicial setbacks could, counterintuitively, contribute to the process of reform. This can happen if lawyers and activist use litigation loss, internally, to construct organisational identity and mobilise outrage constituents, and also use it externally, to appeal to other state actors to initiate reform and by appealing to the public against an antimajoritarian judiciary. ${ }^{98}$

\footnotetext{
${ }^{93}$ As this article concentrates on labour rights enforcement, therefore, the term "strategic labour rights litigation" is used instead of the more general term "strategic litigation."

${ }^{94}$ Rosenberg (2008). However, Rosenberg seems to have modified this pessimistic legal position in a recent jointly edited book on public interest litigation before the Indian Supreme Court. The title of the edited book captures his changed position, A qualified hope. See Rosenberg et al. (2019).

${ }^{95}$ Nejaime (2011), p. 941; Albiston (2011), p. 61.

${ }^{96}$ Nejaime (2011), p. 941; Albiston (2011), p. 61.

${ }^{97}$ Lobel (2003).

${ }^{98}$ Nejaime (2011), p. 947.
} 
(c) A rebellious approach to lawyering that has lawyers work with, rather than on behalf of subordinate persons by recognising the power and expertise of subordinated persons as being critical to the dismantling of the structures responsible for their subordination. ${ }^{99}$ In other words, both lawyers and litigation are just one of the many actors and tools of social change.

(d) Movement lawyering as an alternative to public interest litigation, with its emphasis on mobilised clients and integrated advocacy. It is a strategy based on an genuine bottom-up participation of marginalised groups and "by deemphasizing the centrality of any one type of legal intervention (like impact litigation) in favor of flexibly coordinating organizational and tactical resources across different institutional spaces-some within formal law making arenas and some outside," 100 and in this way, achieving the dual purposes of holding lawyers accountable and achieving effective legal interventions producing social change.

(e) The impact of strategic human rights litigation has to be examined at various levels. Firstly, victims and survivors. Secondly, legal change. Thirdly, political, social and practical change and lastly, democracy and rule of law. ${ }^{101}$

The purpose of the above description of the various approaches is not to engage in a comprehensive and critical analysis of this debate but to show how the approach to SLRL adopted in this section both incorporates, and differs from, the above approaches. The approach to SLRL is based on the following premises: firstly, it concentrates on judicial wins and their impact on social change. This does not imply that the concept of "wining through losing" is not important, but the priority of analysis in this chapter is on judicial wins. This is also because the impact of judicial wins is still a largely misunderstood or understudied phenomenon especially in countries of the Global South. Secondly, it lays down specific criteria for measuring the effectiveness of SLRL in terms of certain basic categories. This lack of clarity in the criterion for measurement is one of the main reasons for the lack of understanding about the real impacts of judicial wins. Thirdly, this analysis is based on accepting the limitations of legal labour struggles, which arise out of the constrained social, cultural, economic and political conditions existing in countries like Pakistan.

One of the central problems in analysing the effectiveness of SLRL is the disagreement in the literature over the criteria to measure the impact of judicial wins on social change. This confusion arises because of two main reasons. Firstly, there is no consensus about what social change implies. For example, does anything short of steps towards the overthrow of capitalism or achieving substantive equality between capital and labour come within the definition of social change in a capitalist system? Does social change have the same meaning as structural or revolutionary change? Secondly, even if there are criteria for measuring social change, these are

\footnotetext{
${ }^{99}$ Lopez (2005), p. 2041; Shah (2017), p. 775.

${ }^{100}$ Cummings (2017), p. 1653.

${ }^{101}$ Duffy (2018).
} 
too vague to measure such social change. For example, vague criteria like disrupting legal and social discourses ${ }^{102}$ or abolishing the basic logic of the system. ${ }^{103}$ Therefore, this chapter proposes that even if precise criteria of how to measure social or structural change may not be possible, it may be possible to come up with conceptual categories which can at least distinguish between different kinds of impacts of litigation on change.

In thinking about such conceptual criteria of measurements, one of the key distinctions is between strategic and tactical impacts. In an important article on this distinction from a Marxist understanding of legal interventions, Robert Knox explains this distinction:

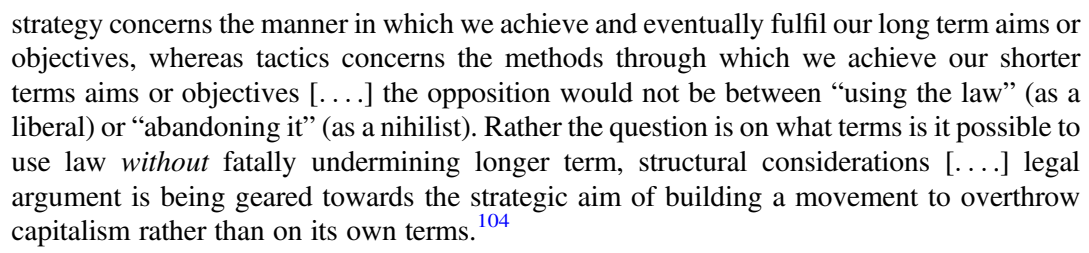

Knox makes a number of crucial points. Firstly, he distinguishes between strategic concerns and tactical concerns. Secondly, he argues that tactical concerns should not be achieved at the expense of strategic concerns and that tactical concerns should always keep in mind the strategic objective of transcending capitalism. But there are two limitations in Knox's analysis. Firstly, structural, systemic or revolutionary change is a multi-faceted phenomenon in complex modern societies. Such structural or revolutionary change cannot only be defined or limited in terms of "a movement to overthrow capitalism" or only in anti-capitalist terms. ${ }^{105}$ Secondly, he fails to make the distinction between strategic and structural or systemic change and it conflates all strategic change as structural or systemic change.

In complex modern societies, legal struggles for structural or systemic change can target various systems of dominations, for example class inequalities, racial or ethnic or religious discriminations, repressive state institutions (e.g. police, intelligence agencies), military dictatorship, regressive or conservative judiciaries etc. Simply because a particular legal struggle does not target the structures of capitalism does not mean that these particular legal struggles cannot have a structural or systemic impact on the system of domination being targeted. In other words, legal struggles having structural or systemic impact are not reducible to only anti-capitalist struggles. This critique of reductionism is important because legal struggles for structural or systemic change targeting systems of dominations other than class inequalities

\footnotetext{
${ }^{102}$ Bader et al. (2019), p. 171.

${ }^{103}$ Knox (2010), p. 199.

${ }^{104}$ Knox (2010), pp. 197, 215, 225.

${ }^{105}$ It is not suggested that Knox does not recognise the importance of overthrowing other systems of domination other than capitalism but the point being emphasised is that this overwhelming and singular focus on the overthrow of capitalism reduces all other struggles against other systems of domination to secondary struggles.
} 
can also contribute towards creating socio-economic and political spaces for such class struggles. For example, class struggles in Pakistan are strategically linked with struggles against military dictatorships because constitutional democracy provides more political space for class struggles than military dictatorships.

Various issues raised above regarding the specific and macro goals of strategic litigation, measuring legal and non-legal impact of litigation through an integrated advocacy approach and connecting tactical gains with strategic objectives, can now be addressed by measuring the impact of judicial wins in terms of three interconnected but distinct categories, i.e. tactical, strategic and structural impact. In terms of litigation impact, tactical impact would mean any change or impact which is limited to conferring benefits on the victims involved in the litigation or which impact is short-term. Strategic impact would mean any impact or change which has more than tactical impact and less than structural impact but rather it creates the strategic space for substantial justice, effective legal reform and increases the capacity and space for social mobilisation but without changing the structural balance of power in state and society. Structural impact would mean impact or changes in both systemic and social terms leading to changes in the balance of power in state and society. Moreover, even within (not simply between) these three categories, the impact or change may vary in different types litigation depending on the level of success achieved in tactical, strategic and structural terms.

On the basis of the above examination of the Baldia factory fire litigation and its interconnected developments, we argue that these cases resulted in tactical victories, created strategic opportunities and openings but ultimately resulted in strategic failures and at the level of long-term and macro impact, it resulted in structural or systemic defeat.

The tactical victories are substantive and obvious: reasonable compensation for the victims, a pensionary scheme under international mediation, initial steps towards registration and inspection of factories and the collective memory of the Baldia factory fire tragedy kept alive through socio-cultural mobilisations. The issue is not to deny the substantive nature of these victories but rather to examine whether these victories are merely tactical or not? Firstly, all orders for the verification and grant of compensation passed by the Sindh High Court were consent orders or interim orders and cannot strictly be used as judicial precedents. Secondly, the ILO mediated pension scheme was voluntary and sets no legal precedent, domestically and internationally. It is at best a voluntary and moral precedent. Moreover, KiK won the case against the victims of Baldia factory fire in Germany. ${ }^{106}$ Thirdly, after the initial orders for registration and inspection of factories throughout Sindh, no further orders or final judgement was passed in this regard by the Sindh High Court. Fourthly, there was not a single large scale demonstration or labour strike in response to the Baldia fire nor has there been any progress towards greater unionisation, even in Karachi, as a consequence of this tragedy.

${ }^{106}$ Bader et al. (2019), p. 156. 
Furthermore, these tactical victories were not connected or translated into strategic success. As explained above, the new workplace safety law, the Sindh Occupational Safety and Health Act (2017) remains an unimplemented paper tiger. Secondly, the passage of this new law cannot overshadow the strategic failures suffered in this case, e.g., no accountability, no judicial precedents in favour of labour rights or enforcement of labour laws, no labour reforms regarding greater labour representation and social security. But these strategic failures were not inevitable or pre-determined because if the tactical objectives of immediate compensation had not overshadowed the strategic objectives of accountability and labour reforms and like compensation, the litigation strategy in the Baldia factory fire litigation had equally prioritised accountability and the improvement of labour conditions of the factories, then the strategic openings created by the Baldia factory litigation might have led to precedent-setting accountability decisions and labour reforms in the textile sector. In other words, the reason for the lack of substantive strategic impact or success of the Baldia factory litigation primarily lies in the lack of social and victim mobilisation for accountability and labour reform resulting in the slow disappearance of any macro or strategic vision during this litigation and the lack of evolution of a legal strategy to effectively operational this strategic vision. ${ }^{107}$

As for the systemic or structural change resulting from the Baldia factory fire litigation, the assessment is quite simple: if there is an absence of strategic victories, then structural or systemic change is impossible to achieve. But more tragically, the defeat on the structural or systemic front is near absolute in the Baldia factory fire litigation. The forces of capitalism had the last laugh when they converted the factory fire from a case involving worker safety and labour law violations into an act of terrorism which resulted in converting the owners of the factory and its government collaborators into victims along with, and at the same level, as the 255 dead workers.

In the midst of this above described treacherous landscape of litigation in countries like Pakistan, can SLRL succeed beyond tactical objectives? In the presence of deunionisation, no political or social sympathy for labour rights, a powerful capitalist elite, a compromised state, no rigorous enforcement of human rights and labour laws, victims who prioritise compensation over accountability and labour reform and a judiciary which is ambiguous towards labour issues and provides relief to victims on the basis of the generic right to life basis rather than on the basis of labour rights, the Baldia factory fire teaches us three basic lessons. Firstly, real tactical victories are possible through SLRL and are worth pursuing for the victims and also in order to explore the possibility of strategic impacts. Secondly, such tactical victories can be translated into strategic openings if the victims can be mobilised to think beyond their concerns like immediate compensation, and if the litigation strategy is able to connect tactical issues with strategic issues by

\footnotetext{
${ }^{107}$ As explained above in the description of the Baldia factory fire litigation, this failure was also due to the fact that the victims prioritised compensation over accountability and labour reform and the fact that there were hardly any victims who were consistently willing to pursue the criminal proceedings against the owners, management and government officials for the purposes of accountability.
} 
prioritising both tactical and strategic objectives simultaneously. But this is not merely a theoretical exercise in strategic thinking but victims, civil society and the political actors have to be convinced and mobilised, and material resources have to be generated, in order for the effective implementation of these linkages between the tactical and strategic objectives. Thirdly, strategic litigation can achieve strategic and structural or systemic impact against other structures of domination. ${ }^{108}$ However, when it comes to inegalitarian capital-labour relations and the dominance of the capitalist elites, SLRL is an ineffective remedy and can have no systemic or structural impact. This conclusion about the ineffectiveness of SLRL in terms of systemic or structural impact is based on the constrained socio-economic and political conditions existing in countries like Pakistan as well as on the basis of the above analysis that there is no immediate hope of escaping the dualism of justice and injustice and law and lawlessness in these labour legal struggles.

\section{Conclusion}

We need to move beyond the dualities of legal nihilism based on theories devoid of evidence from judicial history and legal practice and a legal optimism which celebrates tactical victories without assessing the strategic and long-term impact and damage. Legal struggles are unavoidable because law is omnipresent in modern capitalist societies but law is also strategically addictive for victims and civil society because it does provide justice in labour struggles, however limited it might be. But moving beyond the duality of legal nihilism and optimism does not imply that we can reach some kind of Aristotelian median between them but rather it is to accept the reality of the existence of these irreconcilable contradictions and paradoxes and to build a legal resistance and strategy on the exploitation of these contradictions. ${ }^{109}$ Or as Walt Whitman rightly said, "do I contradict myself? Very well, then I contradict myself (I am large, I contain multitudes).,"110

\footnotetext{
${ }^{108}$ In the context of Pakistan, see the judgment reported as Karamat Ali \& Others v. Federation of Pakistan \& Others (PLD 2018 Sindh 8) on police reform. The aforementioned judgment can be considered as a successful example of strategic litigation leading to strategic impact as not only a new law on policing was introduced but a more independent and accountable police is slowly emerging as a result of this litigation. Also see the judgments reported as Chief Justice of Pakistan Iftikhar Muhammad Chaudhry v. President of Pakistan \& Others (PLD 2010 SC 61) and Sindh High Court Bar Association \& Another v. Federation of Pakistan \& Others (PLD 2009 SC 879) on challenges to military domination and establishing judicial independence. The aforementioned judgments can be considered as successful examples of strategic litigation leading to structural or systemic impact as no military rule has been imposed in Pakistan since December 2007 (the longest period of civilian rule in Pakistan's history).

${ }^{109}$ This analysis is also different from such theories of incremental reformism which presume that in the long run, such contradictions can be resolved. This chapter argues for a theory of reformism which accepts the presence of these irreconcilable contradictions.

${ }^{110}$ Whitman (1855).
} 


\section{References}

Albiston C (2011) The dark side of litigation as a social movement strategy. Iowa Law Rev 941 (96):61-77

Bader M, Saagee-Maaß M, Terwindt C (2019) Strategic litigation against the misconduct of multinational enterprises: an anatomy of Jabir and Others $\mathrm{v}$ KiK. Verfassung und Recht in Übersee 52(2):156-171

Berlin I (1998) The proper study of Mankind, an anthology of essays. Pimlico, London

Brown M (Fall 2018) "An unqualified human good"? On rule of law, globalization, and imperialism. Law Soc Inq J Am Bar Foundat 43(4): 1391-1426

Cole DH (2001) “An unqualified human good": E.P. Thompson and the rule of law. J Law Soc 28 (2):177-203

Comraroff J, Comraroff JL (2006) Law and disorder in the post-colony. University of Chicago Press, Chicago

Cummings S (2017) Movement lawyering. Univ Ill Law Rev 2017(5):1645-1732

Duffy H (2018) Strategic human rights litigation: understanding and maximising impact. Hart, Portland

Gayer L (2019) Putting out the Baldia factory fire: how the trial of Karachi's industrial capitalism did not happen. In: Harriss-White B, Michelutti L (eds) The Wild East. University California Press, Berkeley, pp 288-321

Khan M (2014) Genesis and evolution of public interest litigation in the Supreme Court of Pakistan: towards a dynamic theory of judicialization. Temple Int Comp Law J 28(1):285-359

Knox R (2010) Strategy and tactics. Finnish Yearb Int Law 21:193-199

Lobel J (2003) Success without victory. New York University Press, New York

Lopez G (2005) Living and lawyering rebelliously. Fordham Law Rev 73(5):2041-2054

Mouzelis N (1999) Differentiation and marginalization in late modernity. In: Gough I, Olofsson G (eds) Capitalism and social cohesion. Palgrave Macmillan, London

Mouzelis N (2008) Modern and postmodern social theorizing. Cambridge University Press, Cambridge

Nejaime D (2011) Winning through losing. Iowa Law Rev 96:941-1012

Roa M, Klugman B (2014) Considering strategic litigation as an advocacy tool: a case study of the defence of reproductive rights in Columbia. Reprod Health Matters 22(44):31-41

Rosenberg GN (2008) The hollow hope: can courts bring about social change? University of Chicago Press, Chicago, IL

Rosenberg G, Krishnaswamy S, Bail S (2019) A qualified hope. Cambridge University Press, Cambridge

Schwartz B (1993) A history of the Supreme Court. Oxford University Press, New York, New York

Shah J (2017) Rebellious lawyering in big case clinics. Clin Law Rev 23:775-815

Siddiqi F (2015) Public interest litigation: predicable continuity and radical departures. In: Cheema MH, Gilani IS (eds) The politics and jurisprudence of the Chaudhry Court 2005-2013. Oxford University Press, Oxford

Thompson EP (1990) Whigs and hunters: the origin of the Black Act. Penguin Books, London

Whitman W (1855) Song of myself. In: Leaves of grass. Viking Press, New York 
Faisal Siddiqi is a leading constitutional, civil and human rights lawyer who practices at the Supreme Court and High Courts of Pakistan. Siddiqi graduated from the London School of Economics and Political Sciences and read law at the University of Cambridge. He is one of the main founders of the Rasheed Rizvi Centre for Constitutional and Human Rights, and the Legal Aid Foundation for Victims of Rape and Sexual Assault, where he directly oversees the operations of both organisations. Siddiqi is an active member of the board of directors of the Pakistan Institute for Labor Education and Research. He also regularly writes for the Pakistani daily newspaper Dawn and has been a visiting fellow at the London School of Economics and Political Science and McGill University in Montreal, Canada.

Open Access This chapter is licensed under the terms of the Creative Commons Attribution 4.0 International License (http://creativecommons.org/licenses/by/4.0/), which permits use, sharing, adaptation, distribution and reproduction in any medium or format, as long as you give appropriate credit to the original author(s) and the source, provide a link to the Creative Commons license and indicate if changes were made.

The images or other third party material in this chapter are included in the chapter's Creative Commons license, unless indicated otherwise in a credit line to the material. If material is not included in the chapter's Creative Commons license and your intended use is not permitted by statutory regulation or exceeds the permitted use, you will need to obtain permission directly from the copyright holder. 